\title{
TELE-ODONTOLOGY IN BRAZIL: STRATEGIES AND CHALLENGES FOR THE TRAINING OF THE HEALTH CARE NETWORK
}

\section{Caren Serra Bavaresco PhD', Ana Estela Haddad PhD ${ }^{2}$}

${ }^{1}$ Graduate Programme in Dentistry, School of Dentistry, Lutheran University of Brazil (ULBRA), Canoas, RS, Brazil

${ }^{2}$ Department of Orthodontics and Paediatric Dentistry, School of Dentistry of the University of São Paulo, São Paulo, Brazil

\begin{abstract} indicators should still be better studied.

Keywords: telehealth; primary healthcare; telemedicine; oral health, tele-education; Brazil

BavarescoCS, Haddad AE. JISfTeH 2019;7:e14(1-5).

DOI: https://doi.org/10.29086/JISfTeH.7.e14

Copyright: ${ }^{\oplus}$ The Authors 2019

Open access, published under Creative Commons Attribution 4.0 BY International Licence
\end{abstract}

Different initiatives have been undertaken to guide the telehealth process in the Brazil. The Ministry of Health structured and implemented the Telehealth Brazil Programme initially to cover nine state centres. Later, it expanded the programme to take in the whole country, at which time it became known as the Telehealth Brazil Network. Among the goals of the Telehealth Brazil Network is the development of strategies for clinical training, health education, and training for management, planning and assessment skills, designed for the Family Health Strategy teams. In this context, this paper aims to presents the potential of and difficulties in implementing tele-odontology in Brazil, focusing on teleconsulting, teleeducation and telediagnostic experiences developed to date. It will also present the legal and financial support aspects established in the country, as well as the results found so far in relation to the impacts of strategies and user satisfaction. Finally, suggestions for future perspectives are presented. Related to the strategies implemented in Brazil, it is necessary to analyse the data obtained regarding the successes and failures observed over the years. The positive results obtained with tele-education showed that the Telehealth Programme presents as an efficient tool for the training of the health care network. However, points like the limited use by professionals, some technical limitations and the impact on health

\section{Introduction}

Brazil is a country of continental dimensions, characterised by socioeconomic contrasts, and a heterogeneous distribution of healthcare networks and professional training. Difficulties posed by geographical constraints, lead to differences in the quality of the healthcare services provided in different regions of the country. ${ }^{1,2}$

The Brazilian healthcare system, known as the Unified Health System (SUS), is public and universally accessible. It is based on providing Primary Health Care (PHC) through the Family Health Strategy (FHS). The goal of the reorganisation of the healthcare model was to expand access to health services, by using a comprehensive and longitudinal approach, guided by PHC. ${ }^{2-4}$ In addition, the backbone of the SUS oral health policy includes continuing professional education for oral health assistants, oral health technicians and dentists within the FHS, in order to ensure access to oral healthcare. $^{5}$

The Ministry of Health $(\mathrm{MH})$ published a report on the national epidemiological oral health survey conducted in 2010. It revealed a growing demand for dental care with advancing age, as well as marked regional inequalities in terms of disease experience. ${ }^{6}$ This situation favours the use of new Information and Communication Technologies (ICTs) aimed at improving professional qualifications and achieving greater equality in the provision of healthcare services. $^{7-9}$

Different initiatives have been undertaken to guide the telehealth process in the country. The MH structured and implemented the Telehealth Brazil Programme initially to cover nine state centres. Later, it expanded the programme to take in the whole country, at which time it became known as the Telehealth Brazil Network. By 2015, the programme was active in 22 states, with 6,000 points of Telehealth, located in basic health units of 2,600 municipalities, providing approximately 50,000 FHS professionals potential access to Telehealth services. ${ }^{10}$

Among the goals of the Telehealth Brazil Network is the development of strategies for clinical training, health education, and training for management, planning and assessment skills, designed for the FHS teams. It should be noted that all professionals who constitute the FHS teams are considered users of the telehealth service, including doctors, nurses, nursing technicians and auxiliaries, community health agents, psychologists, nutritionists, social workers, 
pharmacists, dentists, oral health assistants and oral health technicians. ${ }^{2}$

Teledentistry is a form of telemedicine as defined by the Association of American Medical Colleges. It uses telecommunications to send data, graphics, audio, videos and images between localities and people distant from each other for clinical purposes. Teledentistry has the potential to reduce the disparities in rural areas and urban communities by improving dentistry's integration into the healthcare system. Implementing teledental applications necessitates full comprehension and consideration of the healthcare environment and also a commitment to completely integrate teledentistry within that environment. ${ }^{2}$

\section{National regulations}

It is important to consider that the strategies developed by the Telehealth centres are in line with Administrative Order no. 2546 issued by the Ministry of Health and are detailed in the national telehealth manual. ${ }^{2}$ According to Brazilian regulations, Telehealth Brazil Network is managed by the Ministry of Health, state coordination, state management committee, telehealth service and municipal health manager. It is important to note that the telehealth service, or nucleus of telehealth, is composed by the training and management institutions and or health services responsible for the formulation and management of teleconsultation, telediagnostics and formative second opinion. Another important point is that teleconsultation must be carried out between two professionals and teleconsultation between patients and professionals is not allowed in the country.

In order to stimulate the use of Telehealth by the FHS, Administrative Order no. 2859 established a financial incentive for the Telehealth Brazil Networks. The financial incentive for the funding is divided into fixed and variable components. ${ }^{11}$ The fixed component corresponds to $50 \%$ (fifty percent) of the total amount of the monthly financial incentive and is defined according to the potential size of the population served by the telehealth service. The variable component will correspond to $50 \%$ (fifty percent) remaining of the total amount of the financial incentive of monthly cost and is linked to telehealth service's production. ${ }^{10}$

\section{Services offered by Telehealth Brazil Networks}

The Telehealth Brazil Networks offers the following services: teleconsultations, formative second opinion, telediagnosis and tele-education. ${ }^{2,12}$ Teleconsultations can be defined as the consultations carried out among healthcare workers, professionals and managers using ICT. They are held to provide answers to questions about clinical procedures, health actions and the work process. They can be synchronous (performed in real time) or asynchronous (performed through offline messages).

The regular deadline for replying to an asynchronous teleconsultation should not exceed a maximum period of 72 hours from the receipt of the query. The answer should provide knowledge to solve the problem and that will contribute to the continuing education of the professionals involved, with a view to increasing their capacity and autonomy in solving similar cases. ${ }^{12}$

In its turn, second formative opinion is the systematised response to frequent questions, selected according to the criteria of relevance and appropriateness set by SUS guidelines, and is based on the best scientific and clinical evidence available. ${ }^{2,13}$ These questions are available in an open site for consultation by health professionals, separated by the areas of interest.

Telediagnosis is an autonomous service that uses information and communication technologies to perform diagnostic support services over distance. ${ }^{12}$ Tele-education refers to the use of interactive technologies to expand the possibilities of building knowledge, either by increasing access to educational materials in reference centres or the structuring of new educational systems (through distance education or through technologies to support face-to-face education). ${ }^{12}$

In addition to telehealth, other measures were implemented by the Brazilian $\mathrm{MH}$ such as the Open University of the Unified Health System (UNASUS) and the Telemedicine University Network (RUTE). UNASUS aims to expand specialised knowledge development in PHC, using distance learning courses in order to reach a larger number of professionals. ${ }^{14}$ RUTE promotes collaboration between university hospitals, teaching hospitals, health professionals, and students using various interest groups. Health professionals in institutions belonging to RUTE plan a programme of videoconferences and or web conferences to discuss specific themes. ${ }^{15}$

\section{Successes and Failures}

Related to the strategies implemented in Brazil, it is necessary to analyse the data obtained regarding the successes and failures observed over the years. The positive results obtained with tele-education showed that the Telehealth Programme presents as an efficient tool for the training of the health care network. ${ }^{16}$

One of the goals of the Telehealth Programme is to identify the actual learning needs of the PHC professionals and offer strategies to support these needs. This has been done through the provision of large-scale distance learning courses for dental surgeons. ${ }^{12}$ Bavaresco et al., showed that a distance learning course on paediatric dentistry can be an effective tool for improving knowledge of paediatric dentistry in PHC professionals. ${ }^{15} \mathrm{~A}$ pre-test questionnaire consisting of 15 questions was used to assess initial dental knowledge of participants. After the course, participants retook the same initial questionnaire. Participant performance on the dental knowledge questionnaire improved pre- to post-test. These data are in agreement with the results obtained by Monteiro et al. related to the use of distance learning course in the teaching of paediatric radiology. ${ }^{18}$

Moreover, Camargo et al., developed an elearning training course on atraumatic restorative treatment (ART) for 
Brazilian dentists. It seems that elearning has the potential of improving the knowledge that dentists working in the public health system have about ART, especially those with less clinical experience and less knowledge about the subject. ${ }^{19}$

The results of a stomatology course developed by RoxoGonçalves et al., indicated that both dentists and non-dentists have a fairly good capacity for discriminating the nature of oral lesions, but early squamous cell carcinoma is the most challenging situation and remains an issue to be addressed. ${ }^{20}$

Moreover, Morosine et al., analysed the performance of distance diagnosis of dental caries by teledentistry. Clinical examinations were performed to evaluate the decayed, missing, and filled teeth index and oral conditions of each adolescent, documented using a digital camera. For distance diagnosis, two methods of image transmission were tested. Sensitivity ranged from $48 \%$ to $73 \%$, and specificity was either $97 \%$ or $98 \% .^{21}$

Since the diagnosis of oral lesions is often challenging for primary healthcare providers, Telehealth of Rio Grande do Sul created the EstomatoNet, a telediagnosis programme catering to primary care dentists and physicians from southern Brazil. This study included all queries received by EstomatoNet from June 2015 to December 2016. Results indicated that actinic cheilitis, squamous cell carcinoma and inflammatory hyperplasia were the most frequent diagnoses. The intention to refer the patients to face-to-face consultation was reduced from $96.9 \%$ to $35.1 \%$, indicating that telediagnosis has potential to bridging the gap between primary and specialised health care. ${ }^{22}$

When analysing the production of the telehealth services between 2011 and 2015, there is a growing use of the teleeducation and telediagnostic services. However, there is still little use of teleconsultation by health professionals. Moreover, one of the possible obstacles to the use of teledentistry is related to the FHS teams' familiarity with technology.

Another possible impediment to extending the use of these tools has to do with the need to provide the healthcare worker with a time period allocated by management for case discussion. Haddad et al. ${ }^{23}$ pointed out that it is still necessary to overcome barriers in the work process, for the incorporation of permanent education to increase the use of teledentistry. Similar obstacles have been reported in the literature regarding issues of technical reliability, diagnostic accuracy, and the cost-benefit ratio of implementing teledentistry centres. $^{24}$

Another important point to be discussed is related to the evaluation of the impact of tele-odontology strategies on oral health indicators. To date, it has not been possible to establish a relationship between the implantation of telehealth nuclei and improvements in oral health outcomes.

In addition to telehealth, other measures were implemented by the Brazilian $\mathrm{MH}$ such as the Open University of the Unified Health System (UNASUS). UNASUS aims to expand the specialised development in
PHC, using distance learning courses to reach a larger number of professionals. It is built on three pillars, including a collaborative network of higher education institutions, which currently encompasses 35 institutions; an Open Access Educational Repository Collection on Health called (ARES) and the Arouca Platform, totally financed with public funds. ${ }^{25}$

\section{User satisfaction}

Studies previously published in the literature report high rates of user satisfaction in the field of dentistry. ${ }^{26-}$ ${ }^{28}$ The number of professionals satisfied with the Brazilian teledentistry service is high, similar to those reported in the literature. However, the number of professionals who evaluate it is still low (less than $30 \%$ of users provided this information).

\section{Future}

The use of teledentistry and tele-education in dentistry has proved to be a powerful tool for professional training and for increasing the effectiveness of public health. Training oral health professionals in the use of digital media and modifying the work process needs to be done for increasing the impact on the quality of care provided by teledentistry. It is also hoped to analyse the cost effectiveness of the implementation of telehealth in the public and private spheres, as well as in the different regions of the country. The integration of the different types of professional training mediated by distance education, as well as the measures that guarantee the financial sustainability of the projects also deserve to be highlighted.

\author{
Corresponding author: \\ Caren Serra Bavaresco \\ Graduate Programme in Dentistry \\ School of Dentistry \\ Lutheran University of Brazil (ULBRA) \\ Canoas, $R S$ \\ Brazil. \\ Tel: +55 $513477-4000$. \\ eMail: c_bavaresco@yahoo.com.br
}

Conflict of interest. The author declares no conflicts of interest.

\section{References}

1. Brasil. Ministério da Saúde. Portaria n 2.436 , de 21 de setembro de 2017. Revisão de diretrizes para a organização da Atenção Básica, no âmbito do SUS. Diário Oficial [da] República Federativa do Brasil. 2017 set. Available at: http://bvsms.saude.gov.br/bvs/saudelegis/gm/2017/prt2 436_22_09_2017.html accessed 7 May 2019. 
2. Brasil. Ministério da Saúde. Portaria n ${ }^{\circ}$ 2.456, de 27 de outubro de 2011. Redefine e amplia o Programa Telessaúde Brasil, que passa a ser denominado Programa Nacional Telessaúde Brasil Redes (Telessaúde Brasil Redes). Diário Oficial [da] República Federativa do Brasil. 2011. Available at: http://bvsms.saude.gov.br/bvs/saudelegis/gm/2011/prt2 $527 \quad 27 \quad 10 \_2011 . \mathrm{html}$ accessed 7 May2019.

3. Starfield B. Atenção primária: equilíbrio entre a necessidade de saúde, serviços e tecnologias. Brasília, DF: Ministério da Saúde; 2002. Available at: https://www.nescon.medicina.ufmg.br/biblioteca/imag em/0253.pdf accessed 7 May 2019.

4. Arantes LJ; Shimizu HE, Merchan-Hamann E. Contribuições e desafios da Estratégia Saúde da Família na Atenção Primária à Saúde no Brasil: revisão da literatura. Ciênc saúde coletiva 2016;21(5):1499-1510. DOI: https://doi.org/10.1590/1413-81232015215.19602015.

5. Soares CL. Constructing public oral health policies in Brazil: issues for reflection. Braz Oral Res 2012;26 Suppl 1:94-102. DOI: http://dx.doi.org/10.1590/S1806-83242012000700014.

6. Brasil. SB Brasil 2010: Pesquisa Nacional de Saúde Bucal: resultados principais / Ministério da Saúde. Brasília, DF: Ministério da Saúde; 2012:116 p. Available at: http://bvsms.saude.gov.br/bvs/publicacoes/pesquisa na cional_saude bucal.pdf accessed 7 May2019.

7. Haddad AE, Bönecker M, Skelton-Macedo MC. Research in the field of health, dentistry, telehealth and teledentistry. Braz Oral Res 2014;28(1):1-2. DOI: http://dx.doi.org/10.1590/1807-3107BOR2014.vol28.0001.

8. Viana FM. Telemedicina: uma ferramenta para ampliar o acesso à assistência em saúde no Brasil. [dissertação] [Internet]. São Paulo: Universidade de São Paulo; 2015. [acesso em $2017 \mathrm{dez} 09$ ]. Available at: http:// bibliotecadigital.fgv.br/dspace/handle/10438/13314 accessed 9 December 2017.

9. Emami E, Kadoch N, Homayounfar S, et al. Patient satisfaction with E-Oral Health care in rural and remote settings: a systematic review protocol. Syst Rev 2017;6(1):174. DOI: https://doi.org/10.1186/s13643017-0550-3.

10. Brasil. Ministério da Saúde. Custeio dos núcleos de telessaúde: manual instrutivo [recurso eletrônico] / Ministério da Saúde, Secretaria de Atenção à Saúde, Secretaria de Gestão do Trabalho e Educação na Saúde. - Brasília : Ministério da Saúde, 2015. Available at: http://bvsms.saude.gov.br/bvs/publicacoes/custeio_nuc leos_telessaude.pdf accessed 7 May 2019.

11. Brasil. Ministério da Saúde. Portaria no 2.859, de 29 de dezembro de 2014. Institui o incentivo financeiro de custeio mensal destinado aos Núcleos Intermunicipais e Estaduais de Telessaúde do Programa Nacional de Telessaúde Brasil Redes na Atenção Básica, e dá outras providências. Diário Oficial [da] República Federativa do Brasil. 2014 dez. Available at: http://bvsms.saude.gov.br/bvs/saudelegis/gm/2014/prt2 859_29_12_2014.html accessed 7 May 2019

12. Brasil. Ministério da Saúde; Universidade Federal do Rio Grande do Sul. Manual de Telessaúde para Atenção Básica. Brasília: Ministério da Saúde; 2012. Available at: http://189.28.128.100/dab/docs/portaldab/publicacoes/ manual telessaude.pdf accessed 7 may 2019.

13. Tubelo R, Dahmer A, Pinheiro L, Pinto ME. Santa Fé: building a virtual city to develop a family health game. Stud Health Technol Inform 2013;192:798-801. DOI: https://doi.org/10.3233/978-1-61499-289-9-798.

14. de Lima Verde Brito TD, Baptista RS, de Lima Lopes PR, et al. Collaboration between medical professionals: Special interest groups in the Brazilian Telemedicine University Network (RUTE). Telemed $\mathbf{J}$ E Health 2018 Dec 11. [Epub ahead of print] DOI: https://doi.org/10.1089/tmj.2018.0075.

15. Haddad AE, Skelton-Macedo MC, Abdala V, et al. Formative second opinion: qualifying health professionals for the unified health system through the Brazilian Telehealth Program. Telemed J E Health 2015;21(2):138-142. DOI: https://doi.org/10.1089/tmj.2014.0001.

16. Harzheim E, Gonçalves MR, Umpierre RN, et al. Telehealth in Rio Grande do Sul, Brazil: Bridging the Gaps. Telemed J E Health 2016;22(11):938-944. DOI: https://doi.org/10.1089/tmj.2015.0210.

17. Bavaresco CS, Bragança SG, D'Avila OP, et al. Pediatric Dentistry in primary healthcare: creation, development, and evaluation of a distance education course. Telemed J E Health 2018;24(8):624-630. DOI: https://doi.org/10.1089/tmj.2017.0180.

18. Monteiro AM, Corrêa DG, Santos AA, et al. Telemedicine and pediatric radiology: a new environment for training, learning, and interactive discussions. Telemed J E Health 2011;17(10):753-756. DOI: https://doi.org/10.1089/tmj.2011.0049.

19. Camargo LB, Aldrigui JM, Imparato JC, et al. Elearning used in a training course on atraumatic restorative treatment (ART) for Brazilian dentists. $J$ Dent Educ 2011;75(10):1396-1401. PMID: 22012785.

20. Roxo-Gonçalves M, Strey JR, Bavaresco CS, et al. Teledentistry: A tool to promote continuing education actions on oral medicine for primary healthcare professionals. Telemed J E Health 2017;23(4):327333. DOI: https://doi.org/10.1089/tmj.2013.0202.

21. Morosini I de A, de Oliveira DC, Ferreira Fde M, Fraiz FC, Torres-Pereira CC. Performance of distant diagnosis of dental caries by teledentistry in juvenile 
offenders. Telemed J E Health 2014;20(6):584-589.

DOI: https:doi.org/10.1089/tmj.2013.0202.

22. Carrard VC, Roxo Gonçalves M, Rodriguez Strey J, et al. Telediagnosis of oral lesions in primary care: The EstomatoNet Program. Oral Dis 2018;24(6):10121019. DOI: https://doi.org/10.1111/odi.12851.

23. Haddad AE, Silva DG, Monteiro A, Guedes T, Figueiredo AM. Follow up of the legislation advancement along the implementation of the Brazilian telehealth programme. J Int Soc Telemed eHealth 2016;4:e11.

https://journals.ukzn.ac.za/index.php/JISfTeH/article/v iew/141/pdf.

24. Estai M, Kanagasingam Y, Tennant M, Bunt S. A systematic review of the research evidence for the benefits of teledentistry. $J$ Telemed Telecare 2018;24(3):147-156. DOI:

https://doi.org/10.1177/1357633X16689433.

25. Tubelo R, Dahmer A, Pinheiro L, Pinto ME. Santa Fé: building a virtual city to develop a family health game. Stud Health Technol Inform 2013;192:798-801. DOI: https://doi.org/10.3233/978-1-61499-289-9-798

26. Maximino LC, Picolini-Pereira MM, Carvalho JLB. Telegenetics: application of a tele-education program in genetic syndromes for Brazilian students. $J$ Appl Oral Sci 2014;22(6):477-483. DOI: https://doi.org/10.1590/1678-775720130311.

27. Georgsson M, Staggers N. Quantifying usability: an evaluation of a diabetes mHealth system on effectiveness, efficiency, and satisfaction metrics with associated user characteristics. J Am Med Inform Assoc 2016;23(1):5-11. DOI: https://doi.org/10.1093/jamia/ocv099.

28. Ariana A, Amin M, Pakneshan S, Dolan-Evans E, Lam AK. Integration of traditional and e-learning methods to improve learning outcomes for dental students in histopathology. J Dent Educ 2016;80(9):1140-1148. PMID: 27587581. 